\title{
PERIGLACIALNE IN LEDENIŠKE OBLIKE V ZAHODNEM DELU POHORJA
}

Jaroš Obu, univ. dipl. geogr.

Mala Mislinja I3a, SI-2382 Mislinja

e-mail: jaros.obu@gmail.com

Izvirni znanstveni članek

COBISS 1.01

\section{Izvleček}

Nedavna geomorfološka raziskovanja na vzhodnem Pohorju so prinesla nova spoznanja o periglacialnih in ledeniških reliefnih oblikah na tem območju. Na podlagi teh ugotovitev so sledile raziskave podobnih pojavov na zahodnem Pohorju, predvsem krioplanacijskih teras in nivacijskih kotanj. Terenske raziskave so razkrile tudi obstoj potujočih skal, kamnitih tokov, blockmeerov in krnice pod Ribniškim jezerom.

Ključne besede: geomorfologija, periglacialne oblike, poledenitev, krioplanacijska terasa, nivacijska kotanja, krnica, potujoče skale, Pohorje

\section{PERIGLACIAL AND GLACIAL LANDFORMS IN WESTERN PART OF POHORJE MOUNTAINS}

\begin{abstract}
Recent geomorphological research in eastern part of Pohorje Mountains has revealed new information about periglacial and glacial landforms of that area. Based on these findings, similar landforms in western part of Pohorje were studied, especially cryoplanation terraces and nivation hollows. Field research has also revealed the existence of ploughing rocks, blockstreams, blockfields and one cirque.
\end{abstract}

Key words: geomorphology, periglacial landforms, glaciation, cryoplanation terrace, nivation hollow, cirque, ploughing rocks, Pohorje Mountains 


\section{UVOD}

Pohorje je hribovje v severovzhodnem delu Slovenije, visoko do $1543 \mathrm{~m}$. Zgrajeno je pretežno iz kislih magmatskih in metamorfnih kamnin. Gams (2008) je hribovje z reliefnega vidika razdelil na vzhodni planotast in zahodni, bolj slemenasto-dolinasti del. Meja poteka po črti Mislinjski jarek - Šiklarica - dolina Radoljne. Velik del Pohorja je prekrit z gozdovi, le nekateri vršni deli zahodnega Pohorja so poraščeni s travo, ponekod se pojavljajo barja. Na vršnih delih Pohorja so v pleistocenu potekali močni periglacialni in tudi ledeniški procesi (Šifrer, 1974; Culiberg, 1986; Natek, 2007; Gams, 2008).

Po osnovni geološki karti 1 : 100.000 (Mioč, Žnidarčič, 1972) so na območju preučevanja dacit, diaftorit, granodiorit in temen filitoidni skrilavec. Dacit je minerološko podoben granodioritu, le da ima nekoliko izraženo porfirsko strukturo, zato imata podobne fizikalne in kemične lastnosti. Granodiorit se sklenjeno pojavlja na vršnem delu Pohorja vzhodno od sedla med Ribniškim in Malim Črnim vrhom. Zahodno od sedla se na vršnem delu Pohorja pojavlja dacit skupaj z diaftoritom in temnim filitoidnim skrilavcem. Diaftorit je retrogradno metamorforiziran gnajs ter zvezno prehaja v gnajs in blestnik. Danes se izraz diaftorit uporablja redko, zato bom v nadaljevanju uporabljal izraz gnajs. Gnajs se pojavlja skupaj z dacitom med prej omenjenim sedlom in sedlom pri Grmovškovem domu. Zahodno od slednjega se skupaj za dacitom pojavlja temen filitoidni skrilavec, nizkometamorfna kamnina, ki je slabše odporna proti preperevanju (Mioč, Žnidarčič, 1972; Faninger, 1973; Hinterlechner-Ravnik, 1974).

Periglacialne procese in oblike na Pohorju je prvi omenjal Šifrer (1974) v povezavi s periglacialnim drobirjem na pobočjih. Delovanje periglacialnih procesov na vršnih delih Pohorja v pleistocenu je z nivacijskimi kotanjami dokazal tudi Natek (2007). Isti avtor je na pobočjih doline Radoljne prvi opisal sledove poledenitve na Pohorju. Nekaj ugotovitev o periglacialnih in ledeniških oblikah ter procesih je podal tudi Gams (2008).

Namen članka je podrobneje predstaviti periglacialne in ledeniške oblike na zahodnem Pohorju. Periglacialne oblike sem podrobneje morfometrično opisal in primerjal s podobnimi drugod po svetu. Med terenskim delom sem na tem delu Pohorja našel krioplanacijske terase, nivacijske kotanje, kamnite tokove, blockmeere, potujoče skale in krnico.

Periglacialne oblike je na Pohorju opisoval že Natek (2007), a le na vzhodnem Pohorju. Moje preučevano območje je obsegalo vršne dele zahodnega Pohorja.

Za periglacialne procese in oblike sem uporabil podobne izraze kot Natek $(2006 ; 2007)$. Izjema je izraz 'krionivacijska uravnava', namesto katerega sem uporabil izraz 'krioplanacijska terasa' (angl. cryoplanation terrace), ki se pogosteje uporablja v tuji literaturi.

Krioplanacijske terase in nivacijske kotanje so sestavljene iz uravnanega dela (police) in strmejšega dela nad polico (stopnja). Določil sem jim nadmorsko višino, ekspozicijo, naklon, dolžino in širino police ter naklon stopnje. Krioplanacijske terase oziroma nivacijske kotanje, ki visijo v pobočje, sem označil z negativnim naklonom. Njihove police imajo lahko smer največjega vpada vzporedno s pobočjem, oziroma visijo vzporedno s pobočjem. Nadmorska višina se nanaša na višino police, dolžina police je dolžina osi, ki je prečna na smer pobočja, širina police pa je dolžina osi, vzporedne s smerjo pobočja. 


\section{PERIGLACIALNE OBLIKE IN PROCESI}

Izraz periglacialen je vpeljal poljski geomorfolog W. Łoziński. Z njim je označil območja v bližini pleistocenske poledenitve in posledično tudi tamkajšnje podnebne razmere. Izraz se je hitro razširil še na pojave in procese, ki se pojavljajo drugod v podobnih podnebnih razmerah, tako da je postala periglacialna terminologija precej nenatančna, nepopolna in nesistematična, saj imamo pogosto več izrazov za iste pojave ali procese (Embleton, King, 1975).

$\mathrm{Na}$ periglacialnih območjih delujejo različni geomorfni procesi. Najpomembnejši so zmrzalno preperevanje, geliflukcija (soliflukcija), delovanje snega, delovanje vode in delovanje vetra (Embleton, King, 1975). Delovanje procesov je medsebojno tesno prepleteno, njihov splet je na različnih območjih različen, zato ustvarjajo zelo različne reliefne oblike. Nekatere izmed njih le stežka ločimo od ostalih, saj so lahko prehodi med oblikami zvezni.

Izraz 'nivacija' označuje kopico procesov, povezanih z zaplatami snega, ki se obdržijo dolgo časa (Embleton, King, 1975; Rapp, 1984). Uvedel ga je F. E. Matthes, ko je preučeval preoblikovanje površja zaradi zaplat snega v gorovju Bighorn v Wyomingu (Natek, 2007). Pojem nivacija obsega procese preperevanja, erozije, transporta in odlaganja (Thorn, Hall, 2002). Najpomembnejši proces, povezan z nivacijo, je zmrzalno preperevanje, najpomembnejša transportna procesa sta geliflukcija in odtok snežnice. Zaplate snega imajo pri nivacijskih procesih dvojno vlogo. Služijo kot vir snežnice in po drugi strani zaščitijo površje pred temperaturnimi nihanji. Zaradi snežne odeje nastanejo razlike v jakosti zmrzalnega preperevanja, ki je najmočnejše na robovih snežnih zaplat, najmanjše pa pod snegom (Embleton, King, 1975, str. 131).

Najbolj značilna reliefna oblika, ki nastaja z nivacijskimi procesi, je nivacijska kotanja. To so polkrožne kotanje različnih velikosti in oblik, ki so nastale na pobočjih. Nesprijeti material, ki se je sprostil z zmrzalnim preperevanjem, odstranjujeta geliflukcija in odtekanje snežnice. Dna nivacijskih kotanj so nagnjena v smeri naklona pobočja in praviloma niso zaprte kotanje. Na vznožju stopnje lahko imajo nanos pobočnega materiala. Takšne akumulacijske oblike, ki po obliki spominjajo na morene, se imenujejo nivacijske morene (Natek, Gams, Kunaver, 2005; Natek, 2006), v tuji literaturi protalus rampart. Nastanejo na spodnjem koncu strmejših snežišč, kamor polzi preperel material s stopnje (Embleton, King, 1975; Christiansen, 1998).

Nivacijske kotanje lahko razdelimo na tri tipe: prečne (angl. transverse), vzdolžne (angl. longitudinal) in krožne (angl. circular) (Embleton, King, 1975, str. 135-137; Natek, 2007, str. 252):

- Prečne nivacijske kotanje imajo daljšo os prečno na smer pobočja. Lahko so dolge več kot kilometer in široke več $100 \mathrm{~m}$ ter imajo popolnoma ravno dno. Na notranji strani je strmo pobočje z naklonom več kot $30^{\circ}$, saj se naklon povečuje z retrogradnim odmikanjem pobočja zaradi nivacije. V precejšnji meri so lahko strukturno pogojene (z različno kamninsko podlago), vendar lahko začnejo tovrstne nivacijske kotanje nastajati tudi v nepravilnostih na površju, ki niso strukturno pogojene. Prečne nivacijske kotanje predstavljajo predhodno obliko krioplanacijske terase. 
- Vzdolžne nivacijske kotanje imajo daljšo os v smeri nagnjenosti pobočja. Predstavljajo z nivacijo spremenjene povirne dele potokov, oziroma njihovih dolin, kjer so se lahko nabirale večje količine snega.

- Krožne nivacijske kotanje so značilno okrogle do rahlo podolgovate. Neodvisne so od kamninske podlage in predhodnega erozijskega delovanja vode. Najpogosteje se pojavljajo na območjih z majhnimi nakloni in homogeno kamninsko podlago. Premer imajo lahko med nekaj deset metrov do en kilometer.

Nivacijske kotanje so najbolje razvite na območjih, ki v pleistocenu niso bila poledenela. Za razliko od krioplanacijskih teras nastajajo tako $\mathrm{v}$ živoskalni podlagi kot $\mathrm{v}$ sedimentih (Rapp, 1984; Christiansen, 1998).

Izraz 'krioplanacija' je uvedel K. Bryan leta 1946 za opis kombinacije delovanja zmrzali in transporta preperelega materiala po pobočju navzdol zaradi geliflukcije, tekoče vode in vetra (Embleton, King, 1975, str. 159). Večina raziskovalcev uporablja danes izraz 'krioplanacija' v povezavi z opisovanjem krioplanacijskih teras (Thorn, Hall, 2002).

Krioplanacijske terase so blago nagnjene ali skoraj vodoravne reliefne oblike $\mathrm{v}$ živoskalni podlagi na pobočjih, slemenih ali sedlih. Pojavljajo se večinoma na zgornjih in včasih tudi na srednjih delih pobočij. Najpogosteje nastajajo na pobočjih z nakloni do $25^{\circ}$, pri naklonih med $35^{\circ}$ in $40^{\circ}$ se pojavljajo le izjemoma. Naklon police znaša najpogosteje med $2^{\circ}$ in $7^{\circ}$, povsem vodoravne in z nakloni nad $12^{\circ}$ oziroma $14^{\circ}$ so redke. Nekatere krioplanacijske terase lahko visijo tudi prečno na pobočje. Naklon stopnje najpogosteje znaša med $20^{\circ}$ in $40^{\circ}$, vendar so lahko tudi prepadne. Širina teras je najpogosteje med 20 in $80 \mathrm{~m}$ in ponavadi ne preseže $250 \mathrm{~m}$, lahko pa so široke tudi samo nekaj metrov. Dolžina znaša med nekaj deset in sto metri in ponavadi ne preseže kilometra (Czudek, 1995). Usmerjenost, oziroma ekspozicija teras je lahko znotraj istih območij podobna, lahko pa so usmerjene tudi v različne smeri, kar kaže na odvisnost nastanka teh teras od lokalnih dejavnikov (Nelson, 1989; 1998).

Nastanek krioplanacijskih teras še ni povsem zadovoljivo pojasnjen. Večina avtorjev navaja njihov nastanek iz manjših kotanj, kjer je kamnina dobro pretrta ter se nabirata vlaga in sneg, zato je tam tudi najmočnejše zmrzalno preperevanje (Embleton, King, 1975; Nelson, 1989). Pri nastanku sodelujeta dva sklopa procesov: preperevanje in retrogradno odmikanje stopnje na notranji strani kotanje ter odnašanje preperelega materiala. Raziskovalci med procesi preperevanja najbolj poudarjajo zmrzalno preperevanje, najbolj učinkovita procesa odnašanja sta geliflukcija in polzenje materiala zaradi zmrzali (Embleton, King, 1975; Czudek, 1995; Thorn, Hall, 2002). Najpomembnejša dejavnika, ki vplivata na nastanek in razvoj krioplanacijskih teras, sta kamninska podlaga in podnebje (Czudek, 1995).

V literaturi se kot najugodnejša kamninska podlaga za razvoj krioplanacijskih teras omenjajo metamorfne kamnine $\mathrm{z}$ dobro razvito foliacijo ali pretrtostjo, kar je najbolj ugodno za zmrzalno preperevanje (Embleton, King, 1975; Migon, 2003; Aarseth, Fossen, 2004; Hall, André, 2009). Czudek (1995, str. 101) navaja, da so krioplanacijske terase najbolje razvite $\mathrm{v}$ masivnih in dobro razpokanih globočninah.

Pomemben podnebni dejavnik pri nastanku krioplanacijskih teras je temperatura, saj je zmrzalno preperevanje najmočnejše na območjih, kjer je največ prehodov temperature 
pod in nad ledišče. Za zmrzalno preperevanje je ključna vlaga, njen vir so snežne zaplate (Nelson, 1989). Ker se terase razvijejo iz začetnih nepravilnosti, je pomembna tudi prevladujoča smer vetra, ki vanje nanaša sneg (Czudek, 1995). Relief poleg začetnih nepravilnosti vpliva posredno prek mikroklime na nastanek krioplanacijskih teras še z nadmorsko višino, naklonom in ekspozicijo (Hall, André, 2009).

Nejasne razlike med procesoma nivacije in krioplanacije so med raziskovalci sprožile dileme, ali gre morda za isti proces, ki ustvarja različne oblike (Hall, André, 2009). Thorn in Hall (2002) sta po analizi obeh pojmov prišla do ugotovitve, da je nivacija precej bolj uspešno definirana kot krioplanacija. Slednja naj bi delovala v okviru nivacijskih procesov.

Krioplanacijske terase se lahko razvijejo tudi iz prečnih nivacijskih kotanj (Embleton, King, 1975; Czudek, 1995), prav tako se lahko iz nivacijskih kotanj kot prehodne stopnje razvijejo krnice (Christiansen, 1998; Natek, Gams, Kunaver, 2005). Krioplanacijske terase in krnice lahko tudi soobstajajo na območjih, kjer so ali so bili klimatski pogoji mejni za poledenitev (Nelson, 1989).

Nivacijske kotanje in krioplanacijske terase lahko torej zvezno prehajajo ena v drugo, obojne pa v krnice. Ker procesa nivacije in krioplanacije nista zadovoljivo določena, med nivacijskimi kotanjami in krioplanacijskimi terasami ne moremo natančno določiti niti morfometrične niti morfogenetske meje, se pa obe obliki ločita od krnic. Z morfogenetskega vidika lahko krnice ločimo po delovanju ledu. Led lahko prenaša delce tudi v navpični smeri, medtem ko nivacijski transportni procesi tega niso zmožni. Najlažje je nivacijske kotanje ločiti od krnic po usmerjenosti skalnega praga na spodnji strani kotanje, ki je pri krnicah nagnjen navzgor (Embleton, King, 1975; Rapp, 1984; Natek, Gams, Kunaver, 2005). Krioplanacijske terase in nivacijske kotanje so tudi po velikosti praviloma manjše od krnic (Rapp, 1984; Nelson, 1989).

Rezultat periglacialnih procesov je tudi različen material, ki se pojavlja na pobočjih. Zaradi močnega zmrzalnega preperevanja, neporaščenosti in geliflukcije je na pobočjih pogosto debela plast drobirja. Za soliflukcijsko premaknjen material je značilna usmerjenost kamninskih kosov po pobočju navzdol (Embleton, King, 1975; Šifrer, 1974; 1983; Rapp, 1984; Natek, 2007). Pogoste so tudi potujoče skale (angl. ploughing rocks), kamniti tokovi in blockmeeri. Potujoče skale so kosi kamnine, ki potujejo hitreje kot okoliški material in pri tem rinejo tla pred sabo ter za sabo puščajo brazdo (Embleton, King, 1975, str. 118). Kamniti tokovi in blockmeeri so nakopičenja oglatih kamninskih kosov in so posledica močnih periglacialnih procesov (Embleton, King, 1975, str. 168).

\section{KRIOPLANACIJSKE TERASE, NIVACIJSKE KOTANJE IN POTUJOČE SKALE NA ZAHODNEM POHORJU}

Krioplanacijske terase in nivacijske kotanje sem na zahodnem Pohorju našel predvsem na pobočjih južno od glavnega slemena. Našel sem jih tudi severno, vendar so manjše in manj izrazite. Denudacija in ostali geomorfni procesi so v holocenu zabrisali mnoge periglacialne reliefne oblike (Natek, 2007). Zato so mnoge manjše krioplanacijske 
terase in nivacijske kotanje zabrisane, opazne so ostale le največje. Tako so marsikje v vršnem delu Pohorja opazni pregibi, ki bi lahko bili manj izrazite krioplanacijske terase, vendar jih v nadaljnje preučevanje nisem vključil. S podrobnim kartiranjem sem ugotovil 45 krioplanacijskih teras in nivacijskih kotanj, podrobneje pa preučil 25 najizrazitejših na treh ločenih območjih: na severozahodnem pobočju Vavkanovega vrha, na jugovzhodnem pobočju Črnega vrha ter pod slemenom med Pungartom in Otišami. Na prvem območju sem preučil osem, na drugem sedem, na tretjem pa deset krioplanacijskih teras oziroma nivacijskih kotanj.

\section{Slika 1: Preučevana območja na zahodnem Pohorju}

Figure 1: Study areas in western Pohorje Mountains

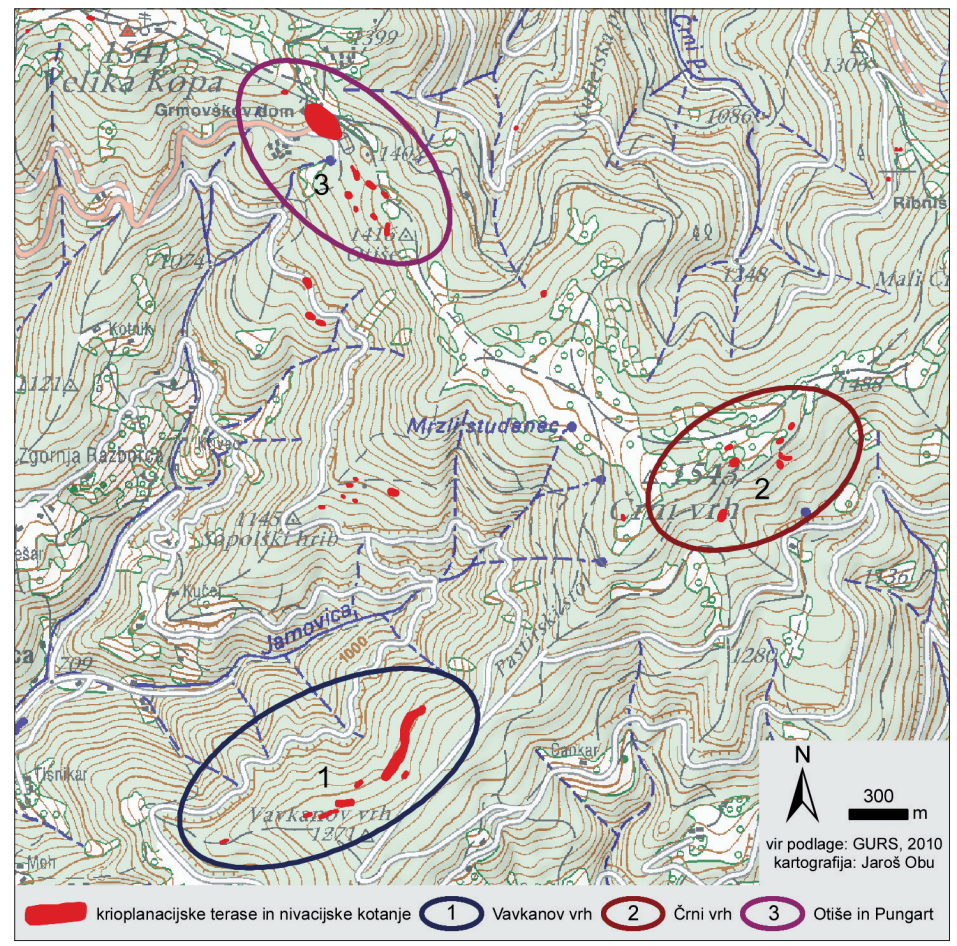

Preučevane oblike se pojavljajo na nadmorskih višinah med $1130 \mathrm{~m}$ na severnem pobočju Vavkanovega vrha in $1525 \mathrm{~m}$ na vzhodnih pobočjih Črnega vrha. Najmanjše merijo v dolžino $20 \mathrm{~m}$ in v širino $5 \mathrm{~m}$. Najdaljša izmerjena dolžina je bila $350 \mathrm{~m}$, širina pa $95 \mathrm{~m}$. Manj izrazite imajo naklon stopnje nekoliko manjši od $20^{\circ}$ in naklon police nad $10^{\circ}$. Najizrazitejše imajo naklon stopnje $38^{\circ}$ in naklon police okoli $0^{\circ}$. Krioplanacijske terase oziroma nivacijske kotanje imajo lahko naklon police negativen ali pa visijo vzporedno s pobočjem. Najbolj podobne so si znotraj preučenih območij, saj so na njihov razvoj vplivali podobni dejavniki. 
Pod Vavkanovim vrhom (slika 2) se krioplanacijske terase pojavljajo med 1130 in $1255 \mathrm{~m}$. Ekspozicije so severovzhodne do severozahodne (azimut med $310^{\circ}$ in $40^{\circ}$ ). Nakloni pobočij znašajo med $14^{\circ}$ in $19^{\circ}$. Police imajo naklon do $6^{\circ}$, tri uravnave rahlo visijo vzporedno s pobočjem in imajo naklon police negativen (št. 1, 2 in 4 na sliki 2). Nakloni stopenj znašajo med $21^{\circ}$ in $32^{\circ}$. Šrina in dolžina največje terase znašata 350 in $50 \mathrm{~m}$, dolžine ostalih teras so med 95 in $36 \mathrm{~m}$, širine pa med 40 in $8 \mathrm{~m}$.

Niz teh oblik se pojavlja na slemenu pod Vavkanovim vrhom in zvezno prehajajo ena v drugo (št. 2-4; slika 2). Med njimi se pregib v pobočju sicer nadaljuje, a je manj izrazit. Nekatere imajo naklon rahlo negativen in visijo vzporedno s pobočjem. Pod tem nizom se pojavi še nekaj posamičnih teras, vendar ne prehajajo ena v drugo. Najnižja terasa je med vsemi najdaljša, saj meri v dolžino 350 m (št. 7 na sliki 2). Je zelo raznolika, z različnimi širinami police in nakloni stopnje, le naklon police se ne spreminja bistveno.

Slika 2: Krioplanacijske terase pod Vavkanovim vrhom

Figure 2: Cryoplanation terraces below Vavkanov vrh

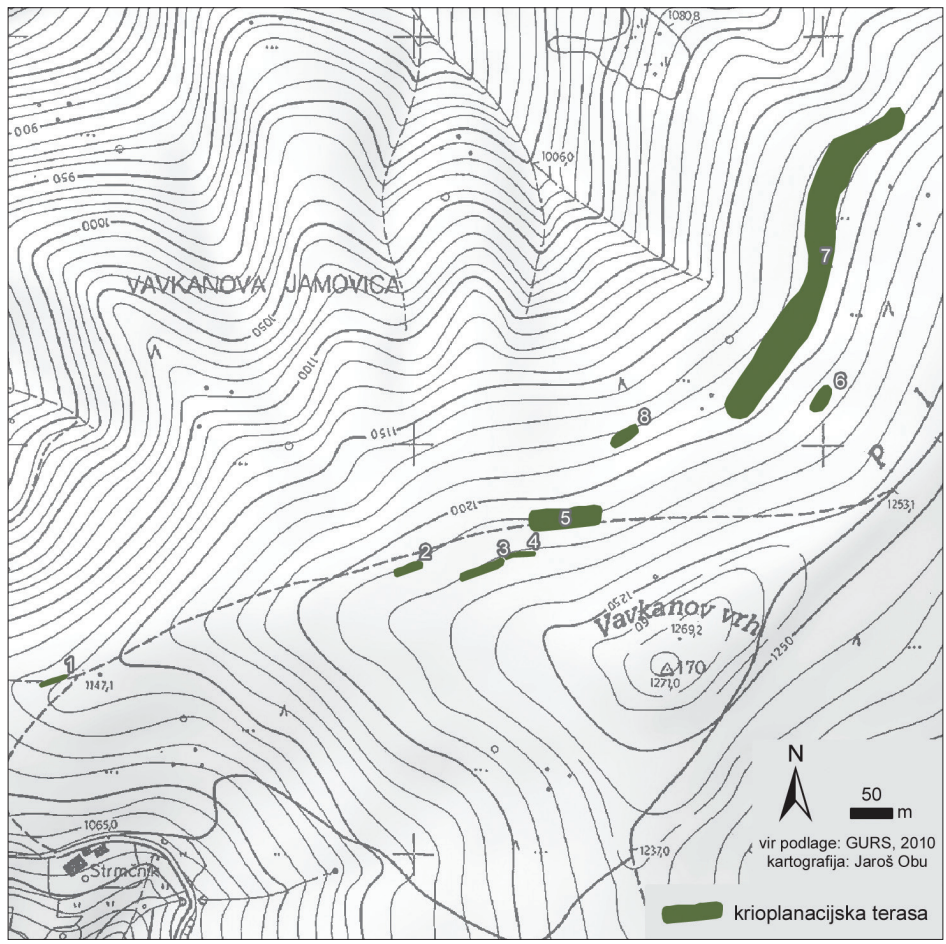

Na drugem območju, pod Črnim vrhom (slika 3), se krioplanacijske terase in nivacijske kotanje pojavljajo med 1440 in 1525 m nadmorske višine. Ekspozicije so jugovzhodne do južne (azimut med $120^{\circ}$ in $160^{\circ}$ ). Nakloni polic so med $3^{\circ}$ in $13^{\circ}$. Zaradi večjega naklona pobočja (med $20^{\circ}$ in $28^{\circ}$ ), na katerem se pojavljajo, so v primerjavi z ostalimi 
območji (nakloni večinoma pod $20^{\circ}$ ) še vedno izrazite. Večji so tudi nakloni stopenj in sicer med $20^{\circ}$ in $38^{\circ}$. Dolžine teras so med 21 in $67 \mathrm{~m}$, širine med 12 in $42 \mathrm{~m}$.

Če te terase primerjamo z ostalimi območji, so tukajšnje oblike krajše v primerjavi z njihovo širino. Oblika št. 12 je celo dvakrat širša kot dolga in predstavlja povirni del potoka. Oblika št. 11 poteka polkrožno okrog pobočja.

Slika 3: Kriplanacijske terase in nivacijske kotanje pod Črnim vrhom

Figure 3: Cryoplanation terraces and nivation hollows below Črni vrh

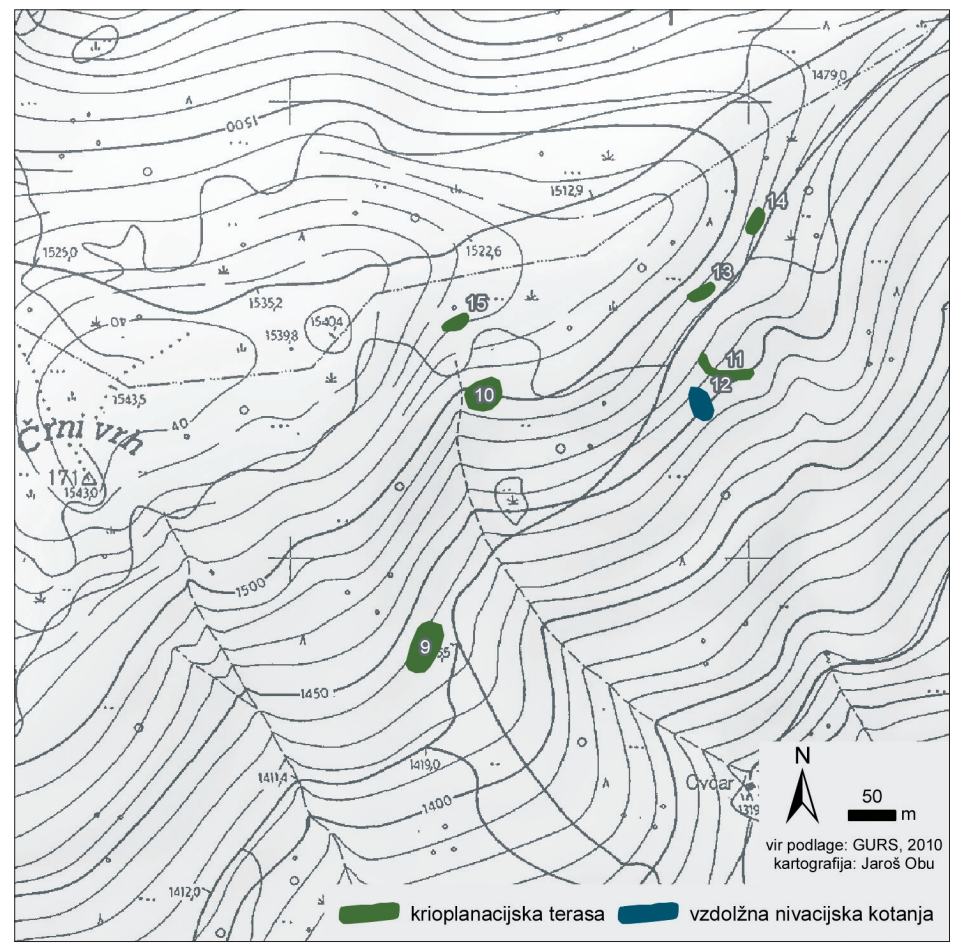

Na slemenu med Otišami in Pungartom (slika 4) se pojavljajo krioplanacijske terase in nivacijske kotanje med 1350 in 1420 m nadmorske višine. Ekspozicije so pretežno jugozahodne (azimut med $175^{\circ}$ in $280^{\circ}$ ). Nakloni pobočij so zelo različni, od $4^{\circ}$ na Pungartu do $25^{\circ}$ pod Otišami. Nakloni polic so različni: dve sta skoraj ravni, tri imajo naklone med $5^{\circ}$ in $10^{\circ}$, na petih je naklon negativen, izmed teh na dveh zelo blago. Dolžina in širina največje znaša 170 in 95 m, dolžine ostalih so med 27 in 56 m, širine pa med 5 in $29 \mathrm{~m}$.

Največja oblika (št. 16 na sliki 4) se nahaja na samem sedlu med obema vrhovoma, na njej stoji Grmovškov dom, zato je tudi delno antropogeno preoblikovana. Vse oblike z negativnim naklonom (št. 17-21 na sliki 4) se nahajajo takoj pod slemenom. Dve izmed teh sta celo nekoliko zaprti in že spominjata na kotanjo, ostale tri visijo 
Slika 4: Krioplanacijske terase in nivacijske kotanje med Otišami in Pungartom

Figure 4: Cryoplanation terraces and nivation hollows between Otiše and Pungart

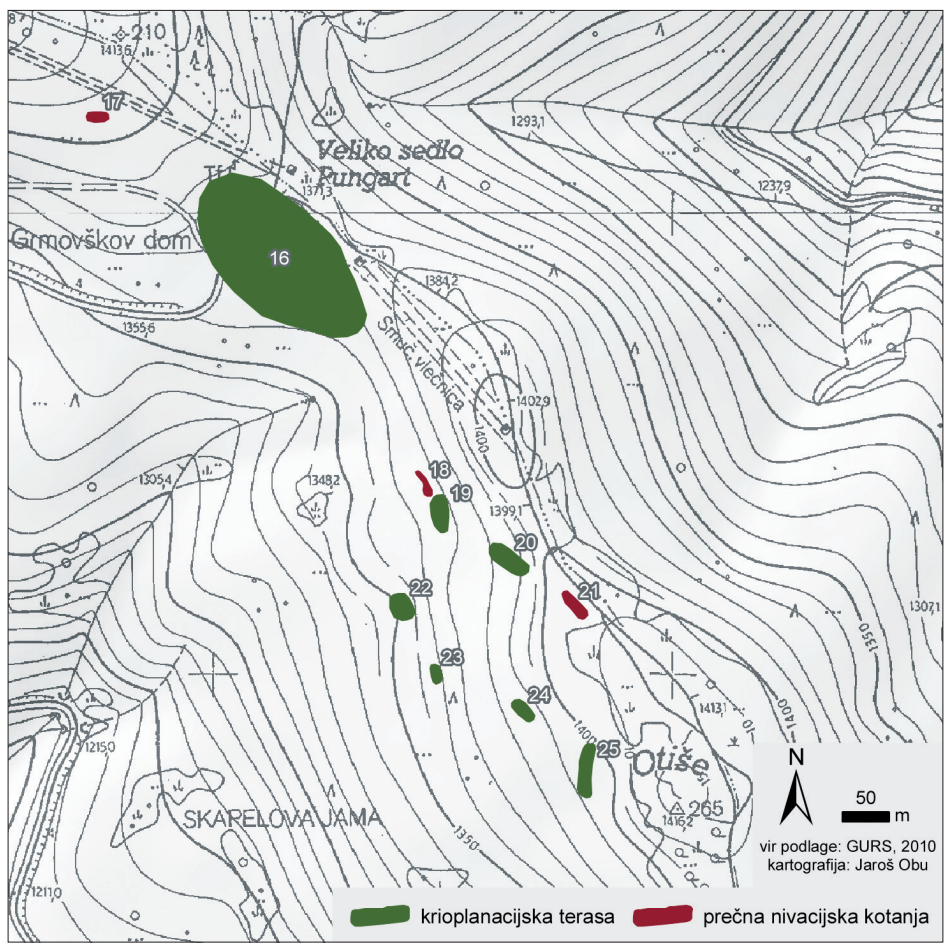

vzporedno s pobočjem. Tri oblike niže na pobočju (št. 22-24 na sliki 4) so manj izrazite in imajo manjšse naklone polic.

Večina morfometričnih lastnosti opisanih reliefnih oblik ustreza značilnostim, ki jih je za krioplanacijske terase navedel Czudek (1995). Nekatere imajo dolžino ali širino le nekoliko manjšo od navedene v literaturi. Poleg tega se pojavljajo v različnih višinah, kar upravičuje uporabo izraza krioplanacijska terasa. Morfometričnemu kriteriju krioplanacijskih teras ne ustrezajo nakloni nekaterih teras, ki so negativni. Nekatere terase, oziroma kotanje, visijo tudi vzporedno s pobočjem, tri izmed teh imajo zaprt obod. Pojavljanje zaprtih obodov in delno tudi negativnih naklonov lahko pojasnimo z nivacijskimi morenami. Glede na nejasne razlike, ki izhajajo iz definicij krioplanacijskih teras in nivacijskih kotanj, sem postavil mejo med oblikama na podlagi naklona police in oboda. Reliefne oblike z opazno negativnim naklonom in zaprtim obodom sem uvrstil med prečne nivacijske kotanje. Reliefno obliko pod Črnim vrhom, ki ima dolžino večjo kot širino, hkrati pa predstavlja povirni del potoka, sem opredelil kot vzdolžno nivacijsko kotanjo. Tako je z morfometričnega vidika izmed opisanih 25 reliefnih oblik 21 krioplanacijskih teras, tri prečne in ena vzdolžna nivacijska kotanja. 
Slika 5: Krioplanacijska terasa pod Otišami (̌̌t. 25 na sliki 4) (foto: A. Celarc)

Figure 5: Cryoplanation terrace below Otiše (No. 25 on Fig. 4) (photo: A. Celarc)

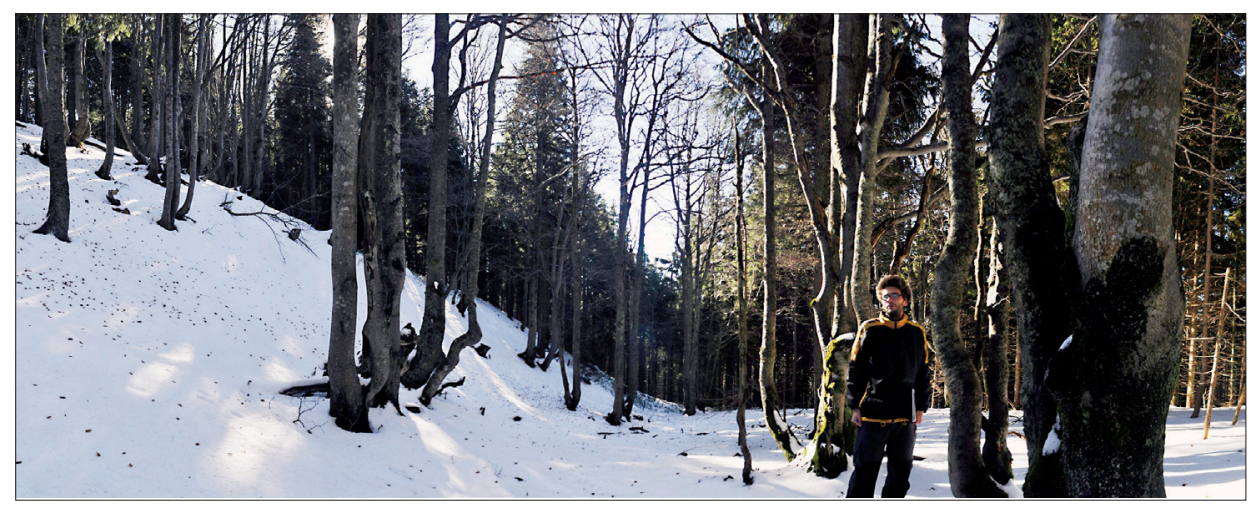

Slika 6: Pogled navzgor po vzdolžni nivacijski kotanji pod Črnim vrhom (št. 12 na sliki 3) (foto: A. Celarc)

Figure 6: Upward view from longitudinal nivation hollow below Črni vrh (No. 12 on Fig. 3) (photo: A. Celarc)

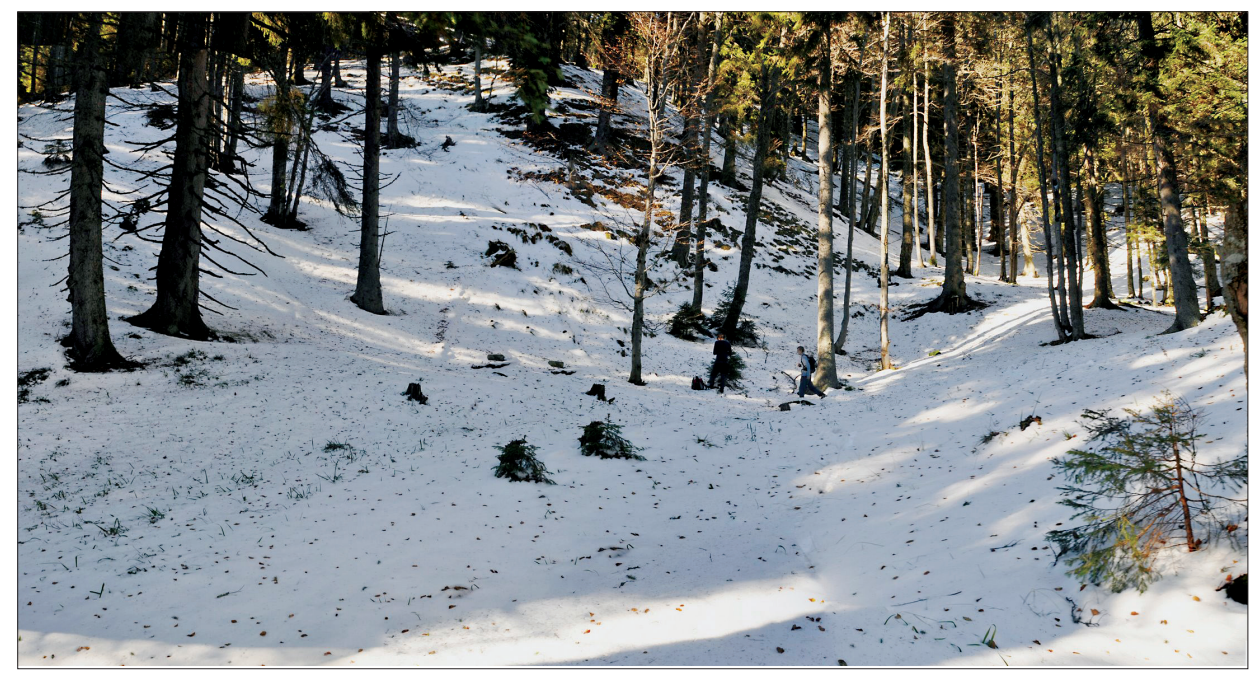

Periglacialni procesi, ki so v pleistocenu ustvarili krioplanacijske terase in nivacijske kotanje, danes praktično ne potekajo več. Fluvio-denudacijski procesi so periglacialne reliefne oblike preoblikovali, zato je ugotavljanje procesov, ki so potekali ob nastajanju teh reliefnih oblik, težavno. Za razliko od vzhodnopohorske planote, kjer je Natek (2007) opisal nivacijske kotanje večjih dimenzij, je zahodno Pohorje slemenasto in kamninsko bolj pestro. Zato so podobni periglacialni procesi, kot so potekali na vzhodnopohorski planoti, na zahodnem Pohorju ustvarili drugačne reliefne oblike. 
Glede na dozdajšnja dognanja o nastanku in odnosih med krioplanacijskimi terasami in nivacijskimi kotanjami (Embleton, King, 1975; Czudek, 1995), bi lahko sklepali na sledeč model razvoja: v morebitnih strukturnih in tudi ostalih nepravilnostih/kotanjah na pobočjih, ki so bila v ledenih dobah nad zgornjo gozdno mejo, so bila pogostejša trajna snežišča, ob katerih so nastale prečne nivacijske kotanje. Ostanki teh so se najbolje ohranili najbližje slemenom. Z nadaljnjim potekanjem periglacialnih procesov oziroma umikanjem stopnje pa so lahko sčasoma nastale krioplanacijske terase.

Največ preučevanih krioplanacijskih teras in nivacijskih kotanj je na gnajsu in ponekod vanj vključenem dacitu. Manj izrazite se pojavljajo tudi na temnem filitoidnem skrilavcu. Na območjih, kjer se pojavljata izključno dacit in granodiorit, jih nisem našel. Najbolj pogosto pojavljanje krioplanacijskih teras na gnajsu se ujema $\mathrm{s}$ predhodnimi ugotovitvami ostalih raziskovalcev, da so najpogostejše na kamninah z dobro razvito foliacijo (Embleton, King, 1975; Migon, 2003; Aarseth, Fossen, 2004; Hall, André, 2009). Natančnejših odnosov med periglacialnimi oblikami in kamninsko podlago ni mogoče analizirati, saj je geološka karta premalo natančna, površje pa prekriva debela preperelina. Gams (2008) je uravnavo pri Grmovškovem domu tolmačil s prehodom dacita $\mathrm{v}$ temen filitoidni skrilavec, a mehanizma nastanka ni navedel. Uravnava morfometrično ustreza krioplanacijski terasi, zato lahko sklepamo na periglacialni nastanek.

Drugi najpomembnejši dejavnik pri nastajanju krioplanacijskih teras je podnebje. Na preučevanem območju sem jih našel na nadmorskih višinah nad $1130 \mathrm{~m}$. Pod to nadmorsko višino temperaturne razmere verjetno niso bile dovolj ugodne za nastanek tako velikih periglacialnih oblik, da bi se lahko ohranile do danes. Čeprav Gams (2008, str. 254) tolmači nastanek krniških ledenikov v dolini Radoljne s hladnimi severovzhodnimi vetrovi, vemo danes o takratnih lokalnih vetrovnih razmerah premalo, da bi lahko ovrednotili njihov pomen za nastanek periglacialnih in ledeniških oblik. Ekspozicija krioplanacijskih teras in nivacijskih kotanj je podobna znotraj vseh treh preučevanih območij, med območji pa so razlike precejšnje in terase so lahko usmerjene v vse smeri. Večinoma imajo enako ekspozicijo kot pobočja, na katerih so nastale. Na osnovi dosedanjega preučevanja nisem mogel ugotoviti vpliva podnebja na velikost, usmerjenost in izrazitost krioplanacijskih teras ter nivacijskih kotanj.

Rezultat periglacialnih procesov je tudi periglacialni pobočni drobir, ki ga je v povirju Dravinje preučeval že Šifrer (1974). Na vršnih delih Pohorja se pogosto pojavlja v obliki kamnitih tokov in blockmeerov, v večjih razsežnostih pod Ribniškim vrhom tudi v obliki potujočih skal (slika 7). Skalni in kamniti drobir je najpogosteje iz dacita in granodiorita, ki sta bolj odporna proti preperevanju kot gnajs in temen filitoidni skrilavec.

Potujoče skale pod Ribniškim vrhom so iz granodiorita. Usmerjenost daljših osi smo izmerili 40 skalam. Povprečna usmerjenost znaša $186^{\circ}$ na prvotno južni ekspoziciji pobočja, standardni odklon je $30^{\circ}$. Izrazita usmerjenost skal z daljšo osjo v smeri pobočja nakazuje nastanek s periglacialnimi procesi. 
Slika 7: Potujoče skale pod Ribniškim vrhom (foto: A. Celarc)

Figure 7: Ploughing rocks below Ribniški vrh (photo: A. Celarc)

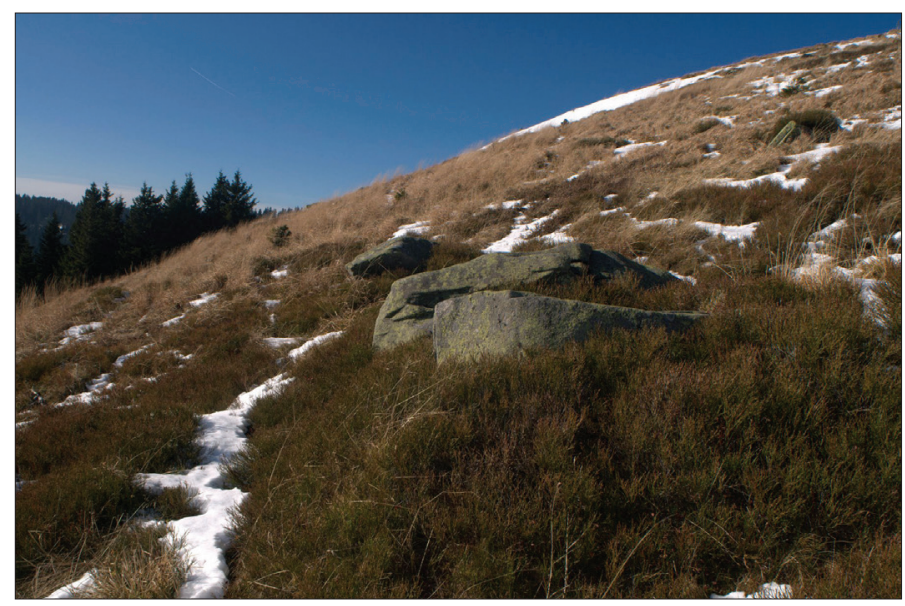

\section{KRNICA JELENOVKA}

Dolgo je veljalo, da ostankov ledenikov iz pleistocena na Pohorju ni. Natek (2007) je prvi opisal krnico Jezerc na vzhodnem pobočju slemena Planinke nad dolino Radoljne. Velika je 780 × 500 m, ima do pet metrov visoko polkrožno čelno moreno, na njenem dnu je zdaj manjše umetno jezero. Južno od krnice Jezerc se nahaja še ena kotanja, ki ima slabše izraženo čelno moreno in je manjših dimenzij. Natek (2007) dopušča tudi neledeniški nastanek te kotanje, medtem ko jo je Gams (2008) označil za ledeniško.

Tretjo kotanjo sem našel 500 m severno od Ribniškega jezera, na severnem pobočju glavnega slemena Pohorja. Dno se nahaja na nadmorski višini $1230 \mathrm{~m}$, zgornji rob na 1470 m. Dolžina kotanje je 510 m, na najširšem delu se razširi do 420 m. V spodnjem delu se kotanja zaključi s polkrožno čelno moreno, ki je na vzhodni strani visoka $10 \mathrm{~m}$, nato se višina proti zahodu zmanjša na pet metrov in proti zahodnemu robu spet nekoliko poveča. V čelno moreno se je po umiku ledenika približno na sredini vrezal potok, ki teče iz kotanje. Na tem mestu so potok umetno zajezili, zato je na dnu kotanje manjše umetno jezero. Na vzhodnem delu morene je lovska koča Jelenovka, čez kotanjo je speljana tudi gozdna cesta. Na levem delu cesta preseka čelno moreno, zato je v profilu lepo viden nesortiran material različne velikosti, značilen za morensko gradivo. Kamninska podlaga na celotnem območju kotanje je granodiorit, iz te kamnine je tudi morenski nasip. Oblika kotanje in prisotnost moren dokazujeta ledeniško delovanje, zato je ta kotanja najverjetneje krnica. 
Slika 8: Čelna morena krnice Jelenovka, v katero se je vrezal potok (pogled proti severu) (foto: J. Obu)

Figure 8: Terminal moraine in Jelenovka cirque, cut by a stream (view towards north) (photo: J. Obu)

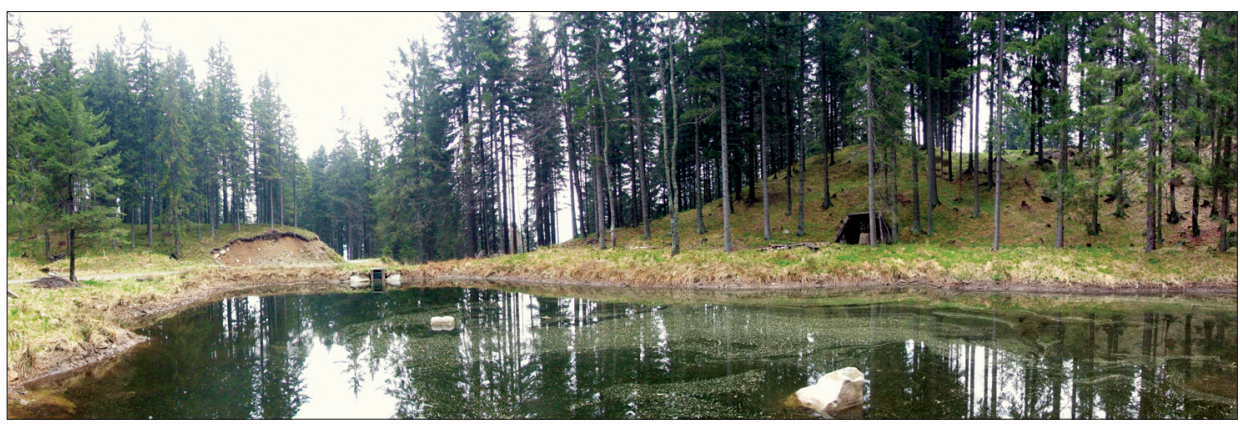

Krnica je bila preoblikovana tudi s periglacialnimi procesi. Vanjo se spuščajo trije večji blockmeeri iz granodioritnih skal; najdaljši se začne na nadmorski višini $1330 \mathrm{~m}$. Kamninski bloki najverjetneje izvirajo iz stopenj, ki so nad blockmeeri (slika 9). Nad temi stopnjami, ki so iz živoskalne podlage, se pojavljajo samo še posamezne skale. Naklon se iz skoraj ravnega dna krnice poveča navzgor na $15-20^{\circ}$, kjer so spodnji deli blockmeerov, v njihovih zgornjih delih je naklon pobočja $30-40^{\circ}$. Na stopnjah nad blockmeeri se pojavijo nakloni tudi prek $40^{\circ}$, nad njimi se naklon pobočja ponovno zmanjša na $30-40^{\circ}$. Na zgornjem robu se krnica konveksno prevesi v pobočje proti Ribniškemu jezeru, na obeh straneh preide v stranski slemeni. Na drugi strani severozahodnega slemena se nahaja erozijski jarek, onstran jugovzhodnega slemena pa neizrazita, močno erozijsko preoblikovana kotanja. Ostankov ledeniškega delovanja tam nisem našel. 
Slika 9: Geomorfološka skica krnice Jelenovka

Figure 9: Geomorphological sketch of Jelenovka cirque

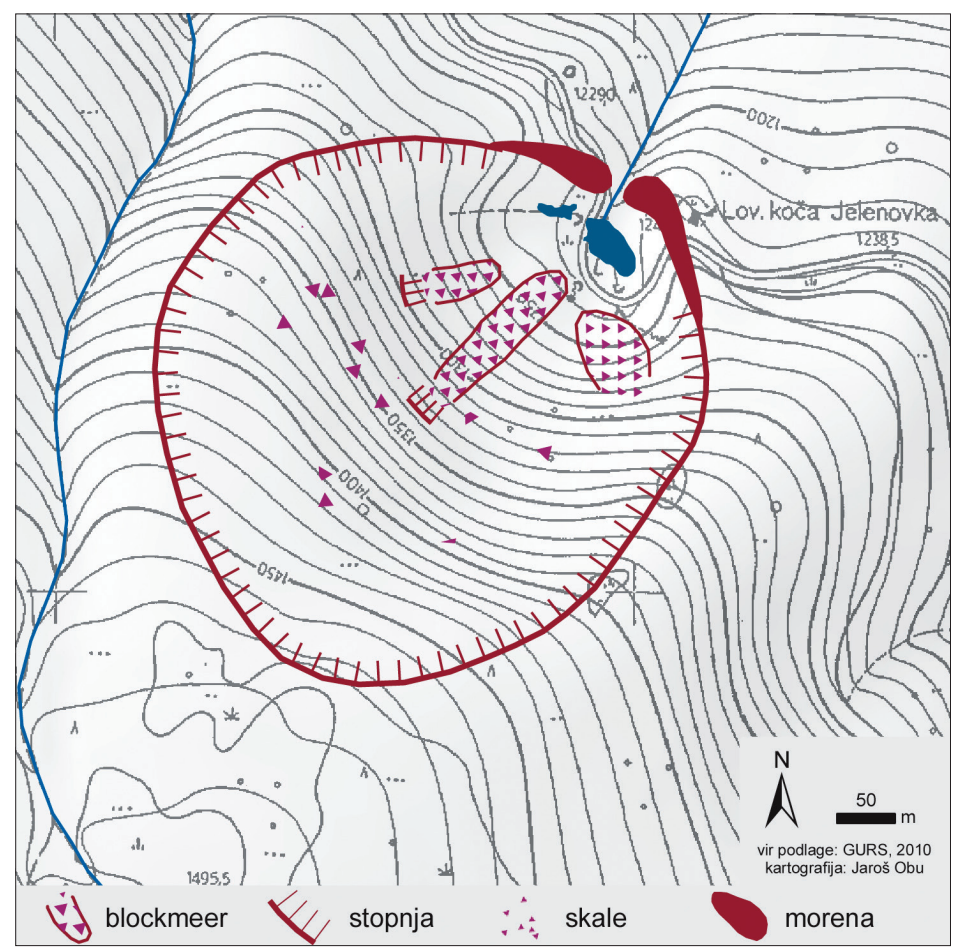

Krnica Jelenovka je po dimenzijah manjša od ostalih dveh do sedaj znanih krnic v dolini Radoljne, a ima kljub temu precej izrazite poteze krnice. Opazno je zajedena v pobočje, ima ravno dno in izrazito čelno moreno, katere gradivo je značilno ledeniško. Dno in vrh krnice sta na približno enakih nadmorskih višinah kot v ostalih dveh krnicah. Ker usmerjenost skalnega praga ni vidna, ne moremo povsem izključiti možnosti, da gre za nivacijsko kotanjo oziroma prehodno obliko. Drobne oblike v kotanji kažejo, da se je tam med zadnjo ledeno dobo najverjetneje nahajal manjši ledenik, hkrati in po umiku ledenika pa so potekali tudi intenzivni periglacialni procesi, kot se je to dogajalo v krnici Jezerc (Natek, 2007, str. 258).

\section{SKLEP}

Pohorje je bilo predmet raziskav z vidika periglacialnega in ledeniškega reliefa šele v zadnjih letih, ko so bile na vzhodnopohorski planoti ugotovljene nivacijske kotanje in dve ledeniški kotanji v dolini Radoljne. Domnevanja o razširjenosti periglacialnih in ledeniških oblik na drugih delih Pohorja (Natek, 2007, str. 259) so se z mojimi raziskavami pokazala za pravilna. Zahodno Pohorje, kjer sem preučeval te pojave, je morfološko 
drugačno od vzhodnega Pohorja, v tamkajšnjem dolinasto-slemenastem reliefu so potekali tudi nekoliko drugačni geomorfni procesi.

Na pobočjih, kjer sem našel krioplanacijske terase in nivacijske kotanje, danes prevladujejo denudacijski procesi, erozijski pa so zelo šibki. Ploskovno odnašanje materiala teži k izravnavanju nepravilnosti v površju, vključno z opisanimi periglacialnimi oblikami. Njihovega nastanka zato ne moremo tolmačiti z delovanjem fluvio-denudacijskih procesov. Prav tako jih ne moremo tolmačiti s strukturnim reliefom, saj je ta zaradi močnih fluvio-denudacijskih procesov slabo izražen. Obstoj rahlo zaprtih kotanj pod slemeni verjetno omogoča odtok padavinske vode skozi preperelino oboda kotanje. Krioplanacijske terase in nivacijske kotanje, ki se pojavljajo na pobočjih zahodnega Pohorja, je z vidika današnjih geomorfoloških spoznanj mogoče tolmačiti kot periglacialne oblike, verjetno nastale v zadnji ledeni dobi, ko so bili vršni deli Pohorja nad zgornjo gozdno mejo (Natek, 2007, str. 259).

Morfološka primerjava preučevanih oblik na zahodnem Pohorju s podobnimi reliefnimi oblikami po svetu je pokazala, da se tu pojavljajo krioplanacijske uravnave in nivacijske kotanje. Mehanizmi nastanka obeh še niso povsem jasni, prav tako ni povem jasna morfološka meja med njimi. Od 25 podrobneje preučenih oblik sem jih na osnovi morfoloških značilnosti 21 opredelili kot krioplanacijske terase in 4 kot nivacijske kotanje. Na intenzivnost preteklih periglacialnih procesov kažejo tudi kamniti tokovi, blockmeeri in potujoče skale.

Kotanja, ki sem jo našel severno od Ribniškega jezera, je opazno poglobljena v okoliško površje in ima lepo izraženo čelno moreno. Na podlagi dosedanjih ugotovitev lahko s precejšnjo verjetnostjo trdimo, da je to krnica, tako da imamo na Pohorju doslej najmanj tri lokacije, kjer so v času zadnje ledene dobe obstajali manjši ledeniki.

Zanimiva je tudi povezava med pojavljanjem ledeniških kotanj v neposredni bližini, oziroma na pobočjih pod barji, kot sta Lovrenško in Ribniško. To povezavo bi veljalo nadalje raziskati. Prav tako bi bilo potrebno podrobneje raziskati morfologijo in odnos med preperelino ter kamninsko podlago na krioplanacijskih terasah in v nivacijskih kotanjah.

\section{Zahvala}

V prvi vrsti se zahvaljujem dr. Karlu Natku za napotke, informacije in pripombe pri raziskovanju ter pisanju članka. Za nepogrešljivo pomoč pri terenskem delu se zahvaljujem tudi Mateju Blatniku in Aljažu Celarcu, za ostalo pomoč pa Jaki Ortarju in Blažu Vičiču.

\section{Viri in literatura}

Aarseth, I., Fossen, H., 2004. Late Quaternary cryoplanation of rock surfaces in lacustrine environments in the Bergen area. Norwegian journal of geology, 84, str. 125-137. Trondheim.

Christiansen, H. H., 1998. Nivation forms and processes in unconsolidated sediments, NE Greenland. Earth surface processes and landforms, 23, 8, str. 751-760. Chichester. 
Culiberg, M., 1986. Palinološka raziskovanja na Lovrenškem in Ribniškem barju na Pohorju. Biološki vestnik, 34, 1, str. 1-14. Ljubljana.

Czudek, T., 1995. Cryoplanation terraces - a brief review and some remarks. Geografiska annaler, series A (Physical geography), 77, 1-2, str. 95-105. Oxford.

Embleton, C., King, C. A. M., 1975. Periglacial geomorphology. London, Edward Arnold, 203 str.

Faninger, E., 1973. Pohorske magmatske kamnine. Geologija, 16, str. 271-315. Ljubljana.

Gams, I., 2008. Geomorfologija Pohorja. Acta geographica Slovenica, 48, 2, str. 185-254. Ljubljana.

Hall, K., André, M.-F., 2009. Some further observations regarding 'cryoplanation terraces' on Alexander Island. Antarctic science, 22, 2, str. 175-183. Cambridge.

Hinterlechner-Ravnik, A., 1974. Pohorske metamorfne kamnine. Geologija, 17, str. 505-507. Ljubljana.

Migon, P., 2003. Cryoplanation - a unique Quaternary phenomenon? Abstracts of XVI INQUA Congress, Geological Society of America. Reno. URL: http://www.dri.edu/ images/stories/conferences_and_workshops/inqua2003/inqua03_abstracts_p63-87. pdf (Citirano 14. 8. 2011).

Mioč, P., Žnidarčič, M., 1976. Osnovna geološka karta 1 : 100.000, list Slovenj Gradec. Zvezni geološki zavod. Beograd.

Natek, K., 2006. Golica (Koralpe) - ekskurzija Geomorfološkega društva Slovenije, 30. 9. 2006. Ljubljana. URL: http://www.geomorfolosko-drustvo.si/Eksk-Golica_ vodnik.pdf (Citirano 14. 8. 2011).

Natek, K., 2007. Periglacial landforms in the Pohorje Mountains. Dela, 27, str. 247263. Ljubljana.

Natek, K., Gams, I., Kunaver, J., 2005. Ekskurzija 1: Geomorfološke značilnosti vršnega dela Pohorja. V: Vodnik po programu, ekskurzijah, predavanjih in povzetkih posterjev. 1. posvetovanje slovenskih geomorfologov, Pohorje 2005, Gorenje pri Zrečah, 21.-23. oktober 2005, str. 5-14. Ljubljana.

Nelson, F. E., 1989. Cryoplanation terraces: periglacial cirque analogs. Geografiska annaler, series A (Physical geography), 71, 1, str. 31-41. Oxford.

Nelson, F. E., 1998. Cryoplanation terrace orientation in Alaska. Geografiska annaler, series A (Physical geography), 80, 2, str. 135-151. Oxford.

Rapp, A., 1984. Nivation hollows and glacial cirques in Söderåsen, Scania, South Sweden. Geografiska annaler, series A (Physical geography), 66, 1-2, str. 11-28. Oxford.

Šifrer, M., 1974. Kvartarni razvoj Dravinjskih goric in bližnjega obrobja. Geografski zbornik, 14, str. 103-178. Ljubljana.

Thorn, C. E., Hall, K., 2002. Nivation and cryoplanation: the case for scrutiny and integration. Progress in physical geography, 26, 4, str. 533-550. London. 


\section{PERIGLACIAL AND GLACIAL LANDFORMS IN WESTERN PART OF POHORJE MOUNTAINS}

\section{Summary}

Pohorje Mountains have been subject of periglacial and glacial landform research for only past few years (Natek, 2007; Gams, 2008). Several nivation hollows have been recognized on eastern Pohorje plateau and two cirques in Radoljna valley. Presumptions about the existence of other periglacial and glacial phenomena in other parts of Pohorje were correct. During my field work, several such landforms have been identified in western part of Pohorje Mountains, too, e.g. cryoplanation terraces, nivation hollows, ploughing rocks, blockfields and one cirque. These landforms do not originate from fluvio-denudational or structurally controlled geomorphic processes, so periglacial and glacial origin was assumed.

Research included 25 most distinctive cryoplanation terraces and nivation hollows identified on upper parts of slopes in western Pohorje Mountains. They exist between 1130 and $1525 \mathrm{~m}$ a.s.l. Their smallest dimensions are $20 \mathrm{~m}$ long and $5 \mathrm{~m}$ wide, the longest is $350 \mathrm{~m}$ long and the widest is $95 \mathrm{~m}$ wide. The least distinctive have tread inclination slightly below $20^{\circ}$ and bench inclination above $10^{\circ}$. The most distinctive one has tread inclination $38^{\circ}$ and almost flat bench. Orientations of cryoplanation terraces and nivation hollows are similar inside small areas, but very diverse in three separate study areas (Figure 1).

Such morphometric characteristics mostly suit to cryoplanation terraces (Czudek, 1995). Other features with slightly inward inclined benches or elongated bottom in slope direction, have more characteristics of nivation hollows. Cryoplanation terraces and nivation hollows in Pohorje Mountains are most distinctive on gneiss, less distinctive are on dark phyllitoidic slate. They seem to be almost absent on dacite and granodiorite. Beside these periglacial landforms, ploughing rocks, blockstreams and blockfields were found. They consist of dacite or granodiorite stones and rocks. Ploughing rocks have longer axis distinctively parallel to slope inclination. This is typical for slope material of periglacial origin.

Cirque Jelenovka to the north of Ribnica Lake has its bottom at $1230 \mathrm{~m}$ a.s.l. and top at $1430 \mathrm{~m}$ a.s.l. and is distinctively deepened into the surrounding area. It is $510 \mathrm{~m}$ long and $420 \mathrm{~m}$ wide, with 5-10 m high terminal moraine which is eroded by small stream that flows out of cirque. Moraine consists of rounded and non-sorted material. Blockfields show that periglacial processes have also been active on the slopes of the cirque. Cirque Jelenovka is smaller than other two in Radoljna valley, but is morphometrically very similar. It was probably formed by similar periglacial processes and, also, the existence of a small glacier during last Ice age can be confirmed.

(Translated by the author) 